\title{
RELATO SOBRE A IMPORTÂNCIA DA UNIVERSIDADE PÚBLICA
}

\section{Priscila Verena Caetano de Lima}

Como é de conhecimento de todas e todos, no Brasil, a educação é um direito assegurado pela Constituição Federal de 1988. Apesar disto, concluir a educação básica e média (sob as quais pesa uma dura realidade de evasão) ainda é, no nosso país, uma árdua conquista. Ter a oportunidade de cursar uma graduação e seguir em uma carreira profissional é uma realização mais atípica ainda, pois o bacharelado ainda é um espaço inacessível para grande parcela da população. Muito embora haja tais incontáveis dificuldades no acesso ao conhecimento de nível superior, ainda há aqueles privilegiados que conseguem as poucas, limitadas e improváveis oportunidades de mudar suas trajetórias de vida por meio de uma graduação. Foi assim comigo.

Desde a formação básica, sempre estudei em instituições públicas. Nunca pensei em cursar o bacharelado, pois pretas/os, pobres e oriundos de favelas não conseguem sequer sonhar com ensino em nível superior, por ser um conhecimento muito distante da nossa realidade.

Lembro-me de que tentei o vestibular para o curso de Direito em uma faculdade privada e acabei passando. Um ano depois, tomei conhecimento de que, na Universidade Federal Rural do Semi-Árido (UFERSA), existia a possibilidade de realizar uma espécie de "prova de transferência". Realizei esse exame e fiquei na quarta colocação, ingressando na UFERSA. O mundo se descortinou e passei a ter acesso a uma educação pública, gratuita e de qualidade - muito graças ao acesso inédito ao tripé ensino, pesquisa e extensão.

Ao relembrar tudo o que passei, é necessário ressaltar como a educação e as oportunidades encontradas na UFERSA mudaram a minha vida. No primeiro ano, consegui passar em um processo seletivo e me tornei bolsista filiada ao Centro de Referências em Direitos Humanos (CRDH) da instituição. Depois, me foi oportunizada uma vaga de estágio no escritório "Hanna Diniz Advocacia”, e, logo após, passei no processo seletivo para o Projeto de Extensão “Acesso à Terra Urbanizada”.

Adentrei no movimento estudantil e compus o Centro Acadêmico de Direito Marcos Dionísio como Presidenta. Terminando o mandato, passei a integrar o Diretório Central dos Estudantes (DCE Romana Barros), atuando na pasta de negras e negros. Concomitante a esse processo, consegui um estágio no Ministério Público do Rio Grande do Norte em Mossoró (na Promotoria do Consumidor) e tive a oportunidade de estagiar no escritório "Davi Advogados Associados".

Após um processo seletivo, lembro com exímio orgulho de que visitei, por uma semana, a Câmera dos Deputados em Brasília, obtendo, então, a conquista de ser a única potiguar a representar o estado do Rio Grande do Norte, o município de Mossoró e a minha amada UFERSA. Integrei, como bolsista voluntária, as fileiras do Projeto de Extensão "Direitos Humanos (DH) na Prática", e também tive a oportunidade de ser estagiária do Tribunal de Justiça da Comarca de Mossoró (na Vara da Infância e Juventude). 
Por fim, ainda na graduação, passei por um processo seletivo em três etapas para uma vaga no curso de pós-graduação em Direito Constitucional e Tributário da UFERSA, o que me propiciou uma bolsa para estudar de forma gratuita e integral nessas searas que tanto adoro. Depois da minha conclusão no curso de direito e ainda enquanto discente do curso de especialização, fui gratificada com a oportunidade de trabalhar no escritório “Tavares e Rocha Advocacia”. Após cinco anos e meio como discente no curso de Direito, comprovei que a educação é o único caminho possível para realização de mudanças.

Por meio dela, aproveitei inúmeras oportunidades, conheci muitas pessoas consideráveis e consegui chegar ao meu atual trabalho, qual seja gerente de uma Unidade Socioeducativa na cidade de Mossoró. É necessário, ainda assim, ser verdadeira e não omitir o que eu vislumbrava enquanto preta, pobre e periférica. Ressalto que tudo o que imaginei e o máximo que pensei que conseguiria era trabalhar como empregada doméstica ou babá, pois esses são os espaços que o mercado de trabalho delega a pessoas como eu. Foi isso que aconteceu com minha avó materna e minha mãe, porém, quando a questão se tornou eu, o padrão foi quebrado e, hoje, sou a única mulher preta da família que continua a alçar voos.

O curso de Direito da UFERSA mudou a minha vida completamente e me proporcionou chegar a lugares inimagináveis. Assim, por mais clichê que pareça, ressalto a necessidade de que os discentes - em especial aqueles membros de minorias marginalizadas - sonhem e tenham objetivos maiores do que suas realidades parecem guardar para eles. Garanto que elas podem ser mudadas: eu sou prova de que isso é possível por meio da educação.

Somente ela é capaz de fazer revolucionar qualquer pessoa e levá-la a habitar locais antes nunca imaginados serem tangíveis. 